\title{
Circulación, difusión y masificación. El futbol en Rosario (Argentina) 1900-1940
}

\author{
DIEGO P. ROLDÁN \\ Universidad Nacional de Rosario/conicet \\ diegrol@hotmail.com
}

\begin{abstract}
Resumen
El artículo se focaliza en los procesos de apropiación, desplazamiento y conflicto en la trayectoria del futbol desde su introducción como una práctica selecta y británica hasta su masificación e integración al imaginario nacional. A través de las repercusiones de partidos internacionales, se reconstruyen las ligaduras que el futbol rosarino estableció con las narraciones del deporte nacional y el estilo criollo. Asimismo, se exploran las condiciones para la profesionalización del futbol a comienzos de la década de 1930 y las sensibilidades activadas durante ese proceso. La última parte del trabajo está dedicada a indagar en torno a las modalidades que adquirió el futbol como espectáculo masivo, donde resulta central la formación de la figura del aficionado, las relaciones sociales mantenidas en los estadios y el vínculo del futbol con el mercado del entretenimiento y el tiempo libre.
\end{abstract}

Palabras clave: futbol; Argentina; cultura; prácticas; difusión social; sociedad de masas

\section{Circulation, Dissemination and Massification. Football in Rosario (Argentina) 1900-1940}

\begin{abstract}
This article focuses on the processes of appropriation, displacement and conflict in the history of the football from its introduction as a select, British practice until its massification and integration into the national imaginary. Through the repercussions of international matches, the article reconstructs the links that football in Rosario established with the narratives of national sport and the Creole style. It also explores the conditions for the professionalization of football in the early 1930 s and the sensibilities activated during this process. The last section of the article is devoted to examining the modalities acquired by football as a mass spectacle, in which the formation of the figure of the amateur, the social relations maintained in stadiums and the link between football and the entertainment market and leisure are crucial.
\end{abstract}

Key words: football; Argentina; culture; practices; social media; mass society.

Fecha de recepción: Fecha de aceptación:

16 de septiembre de $2013 \quad 21$ de octubre de 2013

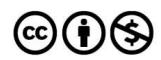




\title{
Circulación, difusión y masificación. El futbol en Rosario (Argentina) 1900-1940*
}

\author{
Diego P. Roldán
}

\section{INTRODUCCIÓN}

$\tau$

as primeras páginas de la historia del futbol argentino están ocupadas tado (Olivera, 1932) que llego desde tado (Olivera, 1932) que llegó desde Inglaterra junto con el ferrocarril y otros adelantos técnicos y civilizatorios. Como lo afirma Stephan Rinke (2007):

la historia temprana del futbol en Latinoamérica es una historia de transferencia cultural, que fue parte de la primera ola de globalización y de la integración de Latinoamérica en el mercado mundial capitalista (p. 87).

En la llamada cuna de los deportes, tempranamente la aristocracia se mostró involucrada en su práctica (Elias y Dunning, 1992, pp. 231-246). Durante la segunda mitad del siglo XIX, el futbol británico atravesó un proceso de difusión social que fue atestiguado por la multiplicación de

* El presente trabajo no hubiese sido posible sin la utilización de los fondos bibliográficos de la extraordinaria colección de la Benson Library de la University of Texas (UT) at Austin, sin la hospitalidad de Javier Auyero y sin el apoyo financiero del CONICET de una beca de estancia post-doctoral en el Department of Sociology de la UT. clubes, el robustecimiento del padrón de socios, la construcción de estadios con mayor infraestructura, la federación de equipos obreros, la estabilización de las reglas de juego y los ensayos en pos de la profesionalización (Curry, 2001; Fishwick, 1989; Holt, 1992; Mason, 1980). Paralelamente, la expansión colonial e imperialista inglesa propagó las prácticas deportivas en áreas distantes del globo. Fue entonces cuando los ingleses exportaron el futbol y otros deportes a las pampas.

En el campo de las ciencias sociales, la antropología, la sociología y la historiografía han prestado atención al pasado del futbol. En Latinoamérica las mayores y más tempranas contribuciones provinieron del campo de la antropología y de los estudios culturales. Estas perspectivas construyeron velozmente al futbol como un objeto para sus investigaciones. Dos interesantes balances al respecto pueden leerse en los trabajos de Alabarces (2000) y Rinke (2007), el primero especialmente atento al campo de las ciencias sociales y los estudios culturales y el segundo más focalizado en la historiografía. Tres autores han escrito las obras más influyentes sobre esta temática en el ámbito rioplatense. Pionero en la delimitación del objeto, el antropólogo Eduardo Archetti (1995, pp. 419-442; 2001; 2003; Dyck y Archetti, 
2003) estudió la construcción del denominado estilo criollo y las relaciones que existen entre el futbol, los imaginarios sociales, la nación, el tango y la masculinidad. Desde una sociología que mantiene estrechos vínculos con los estudios culturales y críticos, Futbol y Patria, de Pablo Alabarces (2002), se interna en una problemática que había permanecido extraña a la agenda de las ciencias sociales argentinas: cómo las narraciones deportivas y futbolísticas inciden en la construcción de la identidad nacional y cómo las identidades nacionales se inscriben en las prácticas futbolísticas. Finalmente, la historiografía de Julio Frydenberg (2011) explora con minuciosidad la formación de este deporte y su derrotero del amateurismo a la profesionalización alrededor de los barrios porteños. Estos estudios han mantenido la atención sobre la ciudad de Buenos Aires y ocasionalmente han ampliado su escala espacial. Cabe destacar la excepción de Cuando éramos footballers, libro en el que Franco Reyna (2011) reconstruye la introducción y los primeros pasos del futbol en la ciudad de Córdoba hasta 1920, en los umbrales de la masificación del deporte.

El presente artículo expresa un cambio de foco y una combinación de las perspectivas anteriormente reseñadas. El observatorio escogido es la ciudad de Rosario. Se trata del segundo centro urbano portuario de la República Argentina, que expresó un temprano y eficaz desarrollo de las prácticas futbolísticas en el país. Formada en la conjunción de varias líneas ferroviarias que conectaban las colonias agrícolas de la provincia de Santa Fe con el puerto más importante del río Paraná, Rosario fue marcada por la inmigración y el comercio. Desde fines del siglo XIX un perfil cosmopolita se extendió por sus calles. El futbol formó parte de esa conexión transoceánica con Europa de la que participaron muchas ciudades portuarias de Latinoamérica (Rinke, 2007, p. 87).

Fundado en 1867, "por caballeros británicos, mayormente dedicados a la construcción del ferrocarril Rosario-Córdoba" (Centenario, 1967, p. 104), el Rosario Cricket Club fue una de las más antiguas asociaciones deportivas de Argentina. En su campo de deportes ubicado en el corazón de la ciudad se jugaron los primeros matches de futbol. En 1899 esos terrenos fueron adquiridos por la congregación salesiana, que a mediados de la década de 1920 levantó en ellos un templo y un colegio. ${ }^{1}$ El club se trasladó a unos terrenos alejados del centro de la ciudad y donados por dos socios caracterizados: los hermanos Carlos y Eduardo Jewell. El solar fue conocido como Plaza Jewell.

Décadas después, cuando el futbol se había difundido a través del espacio social y urbano de Rosario y a raíz del ajuste de la tasa de pavimentos en 1927, el por entonces Club Atlético Rosario (antiguo Rosario Cricket Club) intentó atenuar sus obligaciones vecinales amparándose en el mérito de haber sido el pionner del deporte local. Sin especificar acerca de los deportes que habría introducido, el Atlético se abstuvo de mencionar su papel cardinal en la implantación del futbol. ¿Cuál fue la motivación de esa modestia, de esa omisión o ese borramiento? A comienzos de los años 1930, los estadios atrajeron multitudes que anualmente rozaban el medio

${ }^{1}$ Del Colegio San José al Municipio de Rosario. 22 de octubre de 1919. Expedientes Terminados del Honorable Concejo Deliberante. Mayo 1920, t. 1, f. 337. Archivo del Consejo Municipal de Rosario (ACMR), Argentina. 
millón de espectadores (Anuario, 1941, p. 194). Hacía tiempo que el Club Atlético Rosario (en adelante CAR), pretérito fundador de la Liga Rosarina de Futbol, había declinado su participación de esa actividad y trataba de vincularse con otros deportes. La expansión sociocultural del futbol fue acompañada por el alejamiento del club que lo había introducido en el tejido urbano. Esta paradoja impone otro interrogante: ¿por qué los introductores del deporte se retiraron de los campos de juego y de la competencia futbolística?

En Rosario, el lanzamiento del futbol fue inicialmente exclusivo y estuvo restringido a pocos y pequeños círculos caballerescos que celebraban un ritual de encuentro regulado por el fair play. No obstante, el conjunto de las barreras culturales y sociales que mantenía aislada esa práctica fue desmontada. Las competencias periódicas erosionaron la exclusividad, y la ritualidad primigenia fue trastocada por el avance de la masificación. Este artículo intenta componer un enlace explicativo entre dos imágenes divergentes: la primera donde las canchas y las tribunas estaban ocupadas por pequeños grupos de una elite tendencialmente británica, y la segunda en la que esos espacios se multiplicaron y fueron conquistados por multitudes y jugadores mayoritariamente no británicos. Para ello se propone responder algunos interrogantes en el marco de los estudios culturales acerca de los procesos de construcción, circulación, apropiación y transformación de las prácticas sociales y los bienes simbólicos (Appadurai, 1991) ¿Cuáles fueron las estrategias y las relaciones socioculturales que permitieron ese proceso de diseminación y transformación?, ¿cómo y por qué un deporte inglés y exclusivo devino una práctica de iden- tificación masiva, popular y paulatinamente vinculada al imaginario nacional? Capturar algunas instantáneas de ese movimiento complejo, excavar entre las ruinas de las energías que lo promovieron e intentar desentrañar sus lógicas y paradojas son algunos de los objetivos de este estudio.

$\mathrm{El}$ artículo se inicia con una recapitulación acerca del proceso de introducción y diseminación de la práctica futbolística a comienzos del siglo XX. Se consideran los procesos de formación de clubes, la periodicidad de los partidos y la producción de conflictos sociales y culturales acerca del significado y el sentido del futbol. A través de algunos indicadores, como el impacto de los partidos con equipos de la capital federal, el fallecimiento de un jugador muy destacado, la diseminación de las prácticas futbolísticas en los espacios públicos y las calles de la ciudad, el texto explora algunas aristas del proceso de difusión del futbol en torno a las décadas de 1910 y 1920 . El derrotero de la selección argentina en los torneos internacionales y los choques del combinado rosarino con algunos equipos extranjeros como Chelsea y Barcelona en la segunda mitad de los años 1920 conforman un fecundo yacimiento para la exploración de las relaciones entre la identidad local y la identidad nacional asociada al deporte y las producciones de sentido que comienzan a desplegarse en vísperas y tras la finalización de los cotejos. Además, se estudia el proceso de profesionalización del futbol cruzando un conjunto de argumentos originados en las posiciones sociales, las perspectivas políticas y el ideario de la cultura física. La concurrencia a los estadios, las reformas de sus infraestructuras -que implicaron construcciones más firmes, multiplicación de acondicionamientos, de entradas y sali- 
das, etc.-, la necesidad de multiplicar los medios de transporte encaminados a los estadios, las ritualidades de la hinchada, las pasiones expresadas en el resultadismo y los excesos de la incultura, son algunos de los indicios recogidos por este estudio para explorar el proceso de producción espectacular y masiva del futbol en Rosario a lo largo de la década de 1930.

\section{DE LA INTIMIDAD A LAS TRIBUNAS: COMPETENCIAS Y CONFLICTOS}

El entorno sociocultural del futbol de fines del siglo XIX difería radicalmente del actual. Los directivos se encargaron de apuntalar el carácter británico y excluyente de los primeros clubes. ${ }^{2}$ Hasta 1888 , el CAR continuó llamándose Rosario Cricket Club. ${ }^{3}$ El nomenclador de socios y la arquitectura dejaron que esa exclusividad se inscribiera en las relaciones y las materialidades. Una tribuna pequeña pero ornamentada se colocó a un lado del campo. Muchos espectadores contra el terreno de juego era una postal inimaginable para los patrocinadores del CAR. En cambio, un pequeño espacio para albergar a una concurrencia minoritaria y selecta resultaba adecuado. No hubo alambradas ni barreras que separaran al público de los deportistas. Un solo cerco rodeó las instalaciones como un murallón infranquea-

\footnotetext{
${ }^{2}$ La asamblea de constitución se celebró bajo rigurosa intimidad. Estuvieron presentes A. Wilcox, G. Middleton; W. Penman; V. Parr, A. Le Bas; H. Robinson; Miguel Green; J. Prer; Alberto Le Bas; E. Jewell; G. Topping; Warner y Boardman (Dellacasa, 1939, p. 16).

${ }^{3}$ El cricket fue uno de los deportes ingleses de gran difusión en la India y Australia (Bailey, 1979).
}

ble, numerosas recomendaciones y requisitos fueron solicitados para asociarse. En tributo a la lógica del mutuo (re)conocimiento se organizó el círculo íntimo del CAR. Un grupo de parientes, allegados y amigos disfrutó del ocio y la sociabilidad de sus instalaciones. Las prácticas deportivas dominaron esos momentos ajenos al estruendo de las multitudes.

El CAR mantuvo esa morfología social exclusiva y británica hasta 1930 (Dellacasa, 1939, p. 13). Al iniciarse el siglo Xx, disputó matches de foot-ball con algunos equipos rioplatenses. Lomas, Flores, Quilmes, Belgrano, Retiro, English High School (luego conocido como Alumni) y Peñarol de Montevideo desfilaron por su field. Los matches jugados en el field de Plaza Jewell fueron matizados con reuniones sociales y fiestas. El contacto con los grupos británicos y las elites porteñas fue muy apreciado por los socios del CAR. Estas afinidades se plasmaron en su afiliación a la Argentine Football Asociation, pero posteriormente lo impulsaron a promover la Liga Rosarina de Futbol (en adelante LRF), de tono local.

Con patrones de agregación laborales, inmigratorios y educativos, clubes menos exclusivos crecieron a fines del siglo XIX. Al expandirse la ciudad, los barrios contribuyeron a la formación de nuevos clubes e identidades urbanas. Esas asociaciones fueron sumariamente clasificadas como populares, sobre todo cuando eran objeto de comparación con el exclusivo pionner del deporte rosarino.

El Central Argentine Railway Club fue fundado en 1889 y reconocía al Ferrocarril Central Argentino (en adelante FCCA), compuesto por capitales británicos, como parámetro comunitario. Ciertas exclusiones aparecieron en las regulaciones de su 
actividad: las primeras reuniones fueron protagonizadas por británicos. Hasta 1903 no se aceptaban socios que no fueran directivos, empleados y, en menor medida, trabajadores calificados del FCCA. ${ }^{4}$ Posteriormente, el club se concentró en la popularización y desarrollo del futbol, la patronal ensayó integrar a directivos, personal y obreros en las canchas. Avanzar sobre el tiempo libre de los asalariados era uno de los objetivos de la firma. Los representantes del FCCA supusieron que los triunfos del equipo promoverían la unidad de la empresa. Esa búsqueda de la adhesión obrera fue la clave para popularizar la asociación. El nombre del club fue castellanizado y los requisitos de asociación se flexibilizaron a partir de 1903. Por entonces, el Central Argentine Railway Club pasó a ser conocido como Club Atlético Rosario Central (en adelante CARC).

En noviembre de ese mismo año se creó el Club Atlético Newell's Old Boys (en adelante CANOB). La iniciativa perteneció a los ex alumnos del Anglo Argentine Comercial Scholl dirigida por Isaac Newell. El CANOB disputó el campeonato local desde 1905, convirtiéndose en el ganador sistemático de sus primeras ediciones y el clásico rival del CARC. La peculiar designación del CANOB resistió al paso del tiempo (Alabarces, 2002, p. 49), casi tan lenta como la nacionalización de su nombre fue la popularización del club. Por toda la primera fase organizativa, las relaciones fundacionales de la asociación permanecieron prácticamente inalteradas, ligadas a la tradición de las escuelas británicas.

${ }^{4}$ E. B. Salder, C. Chamberlain, Whitbet, Muthon, H. Cooper, W Malhoil y T. Muton. Se trataba de un club que en principio reunió a superiores y empleados (Dellacasa, 1939, p. 20).
El CARC fue creado por una empresa ferrocarrilera e incluyó una parte considerable del personal, tratando de vincular a los trabajadores de los talleres. El CANOB derivó de un colegio inglés, formado bajo la célebre máxima latina mens sana in corpore sano. Sin alcanzar los extremos del CAR, el CANOB sostuvo ciertos niveles de diferenciación social. Esa tendencia fue acreditada por la composición de las comisiones directivas y los primeros equipos. ${ }^{5}$ En cambio, el CARC contó con el primer player criollo de Rosario: Zenón Díaz. La figura de este futbolista ha sido mistificada, sin embargo su trayectoria ilustra una importante fracción del proceso de popularización del futbol y la afición del CARC. De orígenes humildes, Zenón trabajó en los talleres del FCCA y desde muy joven jugó en la primera división del club. Las comisiones directivas del CARC, más lentamente que los equipos, abrieron paso a nacionales o extranjeros naturalizados (Dellacasa, 1939, pp. 33 y 155). Este movimiento evidenció la flexibilidad institucional de un club originalmente empresarial y la integración de nuevos aficionados al futbol. Si bien los equipos del CANOB se diversificaron socialmente, los directivos sostuvieron un perfil caracterizado. En las décadas de 1910 y 1920 los jugadores argentinos de orígenes populares fueron sus mayores reservas de talento futbolístico.

No todos los clubes contaron con el respaldo de empresas o adherentes poderosos. A veces la creación de estos círculos dependió del voluntarismo y las ansias de competencia. La calle y los descampados

${ }^{5}$ Apellidos ingleses en mayoría; españoles, italianos y suizos-italianos en franca minoría compusieron la formación del CANOB en 1908 (Dellacasa, 1939, p. 39). 
se convirtieron en improvisados campos futbolísticos. ${ }^{6}$ En una ciudad inmigratoria, la sociabilidad masculina se concertó sobre las esquinas, calles y bares. Tan efímera como poco documentada, una miríada de círculos surgió de esos encuentros parcialmente fortuitos (Gayol, 2000). Esas asociaciones apenas poseían camisetas y pelota. No había sede social ni lugar de funcionamiento, las reuniones se efectuaban en un bar o almacén. (Dellacasa, 1939, p. 119). Las instalaciones consistían en un campito usurpado, con algunos postes colocados a modo de arcos. Esos escenarios fueron esquivos a la regularidad. Los juegos empleaban horas y días libres de trabajo, cuando varios partidos se concertaban en una tarde (Roldán, 1959, p. 25). En las primeras décadas del siglo Xx, formar una asociación deportiva no requería trámites ni recursos abundantes. ${ }^{7}$

Entre 1905 y 1915 la casi permanente fundación de clubes atestiguó la difusión del futbol y la diversificación de asociaciones; sus nombres a veces articularon el inglés y se vincularon a los ferrocarriles, las instituciones educativas y las comunidades barriales. ${ }^{8}$ Los círculos británicos con inclinaciones aristocráticas se volvie-

${ }^{6}$ La cuestión de los baldíos. 18 agosto de 1915. Expedientes Terminados del Honorable Concejo Deliberante. Octubre 1915, f. 371. ACMr, Argentina.

7 "El profesor de geometría a un alumno: -A ver, Sr. Morrete ¿Cómo se forma un círculo?-

-Pues... reuniendo varios socios y pidiendo permiso a la autoridad." Extraído de "Humor", Monos y Monadas, 25 de diciembre de 1911, Rosario, p. 20.

${ }^{8}$ Estudiantes (1902) (llamado Argentino en 1904 y desde 1914 Gimnasia y Esgrima); Club Atlético Provincial (CAP, 1903); Sparta Athletic Club (1904; popular como Sparta); The Cordoba and Rosario Railway Athletic Club (1905; popular como Central Córdoba); el nacionalista Tiro Federal Argentino ron escasos. Nuevas voces comenzaron a articular el lenguaje futbolístico y otras corporalidades se involucraron en las prácticas de la pelota.

La multiplicación de asociaciones futbolísticas alertó sobre las posibilidades de establecer un circuito de competencia local. En 1905 se formó la LRF, que promovió la institucionalización de nuevos clubes y fortaleció a los existentes. Pocas asociaciones acordaron la LRF. En la primera reunión estuvieron presentes los representantes del CAR, el CARC, el CANOB y el Argentino (desde 1914, designado como Gimnasia y Esgrima de Rosario). El proceso fue dirigido por el CAR, que diseñó el certamen local para poder lucirse ante rivales débiles y sin experiencia. Además, esperaba ampliar sus bases de reclutamiento futbolístico para enfrentar a los equipos porteños o internacionales. Pero los hechos se distanciaron de las suposiciones y el CAR sólo conquistó el campeonato de segunda división en 1909. Los sucesivos triunfos del CANOB y del CARC lo marginaron de las primeras posiciones por más de una década. Otros clubes también participaron de la LRF, pero con el objetivo de elevar el número de asociados, robustecerse institucionalmente y promocionar al futbol.

Clubes, socios, directivos, aficionados y jugadores de distintos rangos sociales, cooperaron en la difusión del deporte. Rápidamente, la competencia estimuló el interés social que se tradujo en el apoyo de algunos hombres públicos al deporte. A lo largo de tres décadas, los nombres de Santiago Pinasco, Nicasio Vila, Miguel Culaciati, Lisandro de la Torre, Claudio

(1905); Embarcadero (1906; desde 1915 Nacional), y Belgrano (1911). 
Newell, Manuel Pignetto y Luciano Molinas, todos políticos de proyección local, provincial y hasta nacional, instituyeron los premios de varios torneos rosarinos.?

A poco de fundarse, la LRF se unió a la Asociación Argentina de Football (en adelante AAF). Según sus estatutos, la copa "Intendente Santiago Pinasco" se disputaría a perpetuidad, pero en los hechos sólo se jugó por dos años. En numerosos encuentros y campeonatos se establecieron antagonismos irreductibles que fueron conocidos como partidos clásicos. El CANOB y el CARC, durante la primera década de competencia, obtuvieron el mayor número de títulos, la rivalidad de estos dos equipos se profundizó con cada campeonato. Ambos compusieron el clásico local y ganaron la atención de los aficionados. Resuelto en espacios sujetos al pago de una entrada poco costosa, ese duelo captó buena parte de la energía popular.

Con el crecimiento de la expectativa social, aparecieron los reparos del CAR, que abandonó las competencias futbolísticas en 1917 y no volvió a las canchas de ninguna liga. Tan sólo mantuvo un mínimo torneo interno, eligiendo concentrarse en el rugby o el tenis. Dos hipótesis han intentado explicar esta deserción. La primera sostuvo que el CAR fue afectado por

${ }^{9}$ La copa Pinasco fue organizada por la LRF y se disputó entre 1905 y 1907 . Luego pasó a ser la copa de la segunda división jugada entre 1908 y 1930 , inaugurada a raíz de la gran cantidad de jugadores que cada club había logrado reclutar. La copa Nicasio Vila fue instituida entre 1908-1930. Entre los afiliados de la LRF fue la copa de mayor perdurabilidad. La copa Miguel J. Culaciati se jugó entre combinados rosarinos y porteños entre 1912 y 1939. Entre 1913 y 1924, la copa Lisandro de la Torre enfrentó a los equipos de la segunda división para establecer la eliminatoria que promovería el ascenso. la partida de sus mejores players a la guerra de 1914. Debido a esta mengua en los planteles, la dirección afrontó la decisión de retirarse para no arriesgar su prestigio deportivo (Bossio, 1990). La segunda hipótesis afirma que la primera oleada de popularización futbolística (ca. 19051915) contaminó a ojos de los miembros del CAR el deporte. Nuevos aficionados desafiaron la distinción social y las pautas caballerescas que regían un juego de orígenes británicos. El club se creyó obligado a refugiarse en deportes más selectos (Farias y Gauna, 1994).

La recluta de los jugadores del Atlético fue contundente, algunos de esos futbolistas murieron en el frente. ${ }^{10}$ Para 1917 el CAR contabilizaba 326 socios, de los que se enrolaron 104 voluntarios, diez de ellos murieron y uno cayó prisionero (Centenario, 1967, pp. 49-50). Sin embargo, este fenómeno no fue privativo del club. J. Johnson, "discretísimo elemento de la defensa de Rosario Central, murió en la guerra europea en 1917" (Dellacasa, 1939, p. 157). El amateurismo hizo de los jugadores hombres dedicados a otras actividades y muchas veces a varios deportes en simultáneo, ${ }^{11}$ para ellos el futbol fue un pasatiempo entre otros. Las ausencias provocadas por la guerra aumentaron la participación de los elementos criollos en los elencos futbolísticos. Una encrucijada se abrió en la trayectoria del club británico: o emprendían ese camino de integración

${ }^{10}$ Este fue el caso de Duck, guardavalla del Atlético (Dellacasa, 1939, p. 16).

${ }^{11}$ Debido a la menor diferenciación entre los deportes y un tono común a ellos, por ejemplo Ernesto Jewell integró desde muy joven los equipos de rugby (1899) pero también fue, entre 1902 y 1904, centre-half del primer equipo de futbol (Centenario, 1967, p. 28). 
con la sociedad local o bien abdicaban de la práctica futbolística.

El resto de los deportes también cedió jugadores al enrolamiento, sin embargo el rugby recibió mayor impulso justo cuando el futbol declinaba. Por lo visto, la guerra y la desintegración de los planteles no fue el determinante exclusivo del éxodo. El futbol amplió la composición social de los aficionados durante la década de 1910, aún sin alcanzar el rango de espectáculo masivo; ese proceso trastrocó la inicial intimidad de los matches. Alrededor de 1915 el balompié dejó de ser una práctica distintiva, transformándose en una más profana. Manteniéndose en contacto con los campos de futbol, los miembros del CAR arriesgaban su capital social. Al retirarse, preservaron el estilo deportivo caballeresco a salvo de la irreverencia popular. El rugby amateur, deporte de contacto y productor de masculinidades, mantuvo a salvo la distinción de sus socios (Nauright y Chandler, 1996). Frente a un futbol popularizado, los sportsmen hallaron al rugby más elegante y sublime, pese (o justamente debido) a sus reglamentados rigores y rudezas.

Observemos algunas de las incidencias del proceso de difusión social del futbol en la ciudad. Un domingo de septiembre de 1914, el CAR enfrentaba a Tiro Federal (en adelante TF). La pequeña tribuna de Plaza Jewell estaba repleta, los aficionados visitantes se apostaron rodeando el campo. El match comenzó parejo, pero pronto las acciones se desnivelaron. Cuando el juego fue adverso al TF, el clima civilizado se desvaneció. Primero, los jugadores de Tiro cometieron faltas innecesarias y alevosas, jugadas que atentaban contra la contención, la caballerosidad y el ideal británico del fair play. La incapacidad del árbitro para controlar las incidencias del juego desató la violencia. Naranjas mordisqueadas fueron arrojadas al terreno por los simpatizantes del TF, escandalizando a las damas del CAR que presenciaban el cotejo. Poco después, al no revertirse el trámite del partido, los fanáticos invadieron la cancha, adoptando actitudes pugilísticas frente al árbitro y los adversarios. Los directivos del CAR fueron empujados por intentar "salvar la integridad y el buen tono del encuentro". Cuando todo parecía ingobernable, la policía desalojó la cancha, precipitando la conclusión del partido. ${ }^{12}$

$\mathrm{Al}$ año siguiente, el CAR enfrentaba a Sportsman Alberdi, ese cotejo también fue suspendido por invasión de campo y golpes al referee. Estos incidentes muestran conductas "indecorosas" o "incultas", negativamente percibidas por los miembros del CAR, quienes las achacaron a la "excesiva popularización" del deporte. A su criterio, había muchos espectadores que

por su desmedido apasionamiento cometían actos reñidos con el orden [...] aficionados al futbol, que pagan entrada, los seguidores sin afiliarse a ningún club, aun cuando son fanáticos partidarios de los colores de alguna casaca, lo que se ha dado en llamar hinchas (“Centenario", 1967, p. 98).

Este grupo convirtió a los distinguidos fields en escenarios semejantes a los tablados carnavalescos.

La comercialización del deporte se hacía cada vez más evidente, no sólo en el corte de entradas sino también en los campos de juego. El CANOB denunció el profesionalismo encubierto; durante el cam-

${ }^{12}$ Excesos futbolísticos. La Capital, 21 de septiembre de 1914, p. 4. 
peonato de 1917 , los mejores jugadores de Gimnasia y Esgrima Rosario (en adelante GER) revistaban como empleados del club. Julio Libonatti y Ernesto Celli cobraron un sueldo a cambio de sus servicios futbolísticos. No cumplían otra función que la presunta limpieza de las instalaciones, aunque nadie pudo hallarlos en sus puestos de trabajo. Esas remuneraciones diferidas eran antirreglamentarias e ilegales, y recibieron la designación popular de "marronismo". ${ }^{13}$ Malquistada con el GER, la dirigencia del CANOB impulsó las acusaciones para obtener puntos suplementarios en el torneo. Los defensores del deporte amateur se manifestaron contrarios a estas acciones corruptoras del deber ser del sport. Al año siguiente, las imputaciones se aquietaron. Entonces, los jugadores en litigio pasaron a las filas del CANOB, mostrando los objetivos pragmáticos de aquella condena moral.

Las manifestaciones de (in) cultura de los hinchas y las sospechas de "profesionalización encubierta" justificaron el éxodo de los sportsmen ingleses. El CAR se sintió acorralado por la popularización de las tribunas y la protoprofesionalización del deporte. Al rescindir el vínculo con la LRF, el club no se inscribió en otros certámenes y abandonó de manera indeclinable la práctica futbolística.

Esta desafectación no fue excepcional, también en 1920 el GER renunció a la LRF. Diversos episodios marcaron esa decisión. Desde 1917, la LRF estableció que los

\footnotetext{
${ }^{13}$ Nombre con el que se conoce la etapa amateur del futbol argentino, en la que muchos jugadores eran compensados por su participación en los equipos con pagas ilegales. Esos dineros, según se dicen, eran depositados por los dirigentes en el interior de los botines marrones de la década de 1920 (Roldán, 1959, p. 26).
}

encuentros interprovinciales, internacionales y excepcionales se jugarían alternativamente en las canchas del GER y del CANOB. Eran los partidos que concentraban el máximo número de espectadores y que arrojaban recaudaciones abultadas. No obstante lo convenido, todos los encuentros se desarrollaron en el estadio del CANOB. Según el GER, ese favoritismo obedecía a la familiaridad del CANOB con la LRF, cuya presidencia era ocupada por gente de su núcleo: Claudio Newell y Sebastián García (Dellacasa, 1939, p. 8).

Otros episodios de incultura impulsaron la salida del GER de la LRF. El 22 de junio de 1919 falleció José Schiavini, de la quinta división del GER; el funeral se realizó en el horario previsto para un partido de esa divisional con la análoga del CARC. Naturalmente, los clubes convinieron la suspensión, pero la LRF otorgó los puntos al CARC. ${ }^{14}$ Esa resolución enfrentó dos maneras de entender el deporte. La LRF sostuvo que de no presentarse uno de los contendientes, los puntos serían capitalizados por el rival. Nada significaba la muerte de un jugador, las causas de la ausencia eran irrelevantes. La maquinaria tendencialmente profesionalizada y anónima del futbol se estaba forjando y desautorizaba el honor y el fair play de los sportsmen. Al reclamar un fallo más justo, el GER subrayó "la cultura y nobleza ingénita de nuestros sportsmen", la misma que había sido mancillada por la decisión de la LRF y su "fanatismo resultadista". ${ }^{15}$

Pero las querellas entre el GER y el CANOB no se detuvieron. En el partido entre el GER y el CANOB de 1919, una

\footnotetext{
${ }^{14}$ Documentación. 1920, p. 15. Club Gimnasia y Esgrima de Rosario (CGER), Argentina.

${ }^{15}$ Documentación, p. 16. CGER, Argentina.
} 
mala actuación del árbitro produjo jugadas bruscas. Un futbolista fastidiado se quitó la camiseta, ruborizando al "público de señoras y señoritas que presenciaban el espectáculo.” El subsecretario del CANOB "estuvo provocando durante el partido con expresiones gruesas, hasta llegar al insulto y el pugilato". ${ }^{16}$ Un año después, la final de la Copa Vila enfrentó al CARC y al CANOB en un campo neutral y acondicionado: la cancha del GER. Al invadir los hinchas el campo de juego la victoria del CARC fue rubricada por numerosos destrozos. Los alambrados y la casilla de jugadores visitantes fueron literalmente arrasados a puntapiés. Ante la "pérdida" (léase robo) de pelotas e infladores, el GER solicitó un resarcimiento a la LRF. El CARC cubrió los daños, pero el perdedor (CANOB) objetó el monto. La LRF, dirigida por miembros del CANOB, hizo lugar a ese reclamo. El GER jamás pudo cobrar las reparaciones y, en consecuencia, presentó, en nombre de la "cultura deportiva honorable" y en contra del "inculto hinchismo resultadista, su renuncia a la LRF."17

Estos episodios muestran las posiciones acerca de la diseminación social y protomercantilización deportiva. Eliminados clubes como el CAR y el GER, se activaron las gramáticas de la popularización futbolística. También, las actitudes de los cultores y espectadores del deporte desbrozaron un camino de transformación.

\section{DESPLAZAMIENTO Y APROPIACIÓN}

La expectativa depositada en el futbol creció a lo largo de la década de 1920. Los parti-

${ }^{16}$ Documentación, p. 16. CGER, Argentina.

${ }^{17}$ Documentación, p. 9. CGER, Argentina. dos de los combinados rosarinos con equipos extranjeros fascinaron a la afición. Esa relevancia produjo las condiciones que la profesionalización subordinó a su lógica. Luego de una consagratoria gira europea en 1925, el equipo de Boca Juniors visitó Rosario para medirse con el combinado de la LRF. El público que acudió al estadio del CANOB fue tan nutrido como variado. La prensa narró la masificación de un espectáculo capaz de atraer a un espectro social que abarcaba desde peatones hasta automovilistas.

Si se tiene en cuenta el interés extraordinario que había tenido la virtud de provocar en todos los círculos sin distinción, el anuncio del match concertado para hoy entre el justamente célebre eleven porteño de Boca Juniors y un conjunto seleccionado entre los mejores jugadores pertenecientes a la Liga Rosarina de Football, no es de extrañar que, no obstante la temperatura destemplada, comenzara al promediar el día, a afluir en una columna interminable de peatones, automóviles y carruajes, la enorme concurrencia que más tarde habría de llenar totalmente las amplias y cómodas instalaciones del conocido estadio de Newell's Old Boys. La distribución de las puertas de acceso en diversos costados del campo, el servicio de vigilancia policial y la numeración de los asientos reservados alrededor del field, fueron algunos de los detalles que evidenciaron una organización esmerada y contribuyeron indiscutiblemente al mayor realce de la extraordinaria fiesta deportiva. ${ }^{18}$

El municipio donó la copa "Sol y Tierra” y el intendente Pignetto, caracterizado

${ }^{18}$ Partido amistoso entre el Club Atlético Boca Juniors y el combinado de la Liga Rosarina de Football. La Capital, 26 de agosto de 1925, p. 5. 
higienista y promotor de la cultura física nacional, dio el puntapié inicial, atando simbólicamente la política municipal con el deporte. Muy tempranamente el futbol rebeló sus virtudes como un poderoso vehículo, a veces mediado e indirecto, para la construcción de una propaganda política.

Antes de comenzar, los jugadores homenajearon con un minuto de silencio al recientemente desaparecido Ernesto Celli, quien pasó por Colón de Santa $\mathrm{Fe}$, el GER, el CANOB y el seleccionado argentino. El jugador internacional fue sorprendido por una muerte prematura en la cúspide de su carrera. Días antes, una verdadera multitud se congregó en su sepelio, hombres enlutados patentizaron la atracción ejercida por el deporte.

Pocas veces habrase tributado un homenaje tan general y hondamente sentido a un cultor del sport, en cualquier de sus manifestaciones. Horas antes de la señalada, la ceremonia y ya se preveía habría de alcanzar insultados contornos, continuaba el desfile de amigos y compañeros del renombrado footballer, iniciada el día anterior. Centenares de socios de los clubes locales se estacionaban ya en las inmediaciones del domicilio [...] El féretro cubierto por los colores del Club Newell's Old Boys que defendió en tantas oportunidades fue sacado de la casa de su familia [...] durante media bora fue interrumpido el tráfico al paso de la larga columna que habría alcanzado el aspecto de una manifestación popular [...] irreparable pérdida que significa para el deporte y la sociedad, la desaparición de tan magnífico atleta y perfecto caballero. ${ }^{19}$

${ }^{19}$ El sepelio de Celli dio margen ayer a importante demostración de pesar. La Capital, 5 de marzo de 1925 , p. 6.
Celli murió en Rosario, después de un amistoso con Nacional de Montevideo, la prensa se reservó las circunstancias del deceso. Con sus exequias, dos cuestiones quedaron remarcadas. Por una parte, se hizo visible la cantidad de aficionados y la devoción que tributaban a un jugador destacado. Por otra, se pusieron de relieve las condiciones de construcción social y cultural del héroe futbolístico de masas, nacidas en el tráfico suspendido de las calles de Rosario, en medio del recorrido de ese largo cortejo.

Luego de una exhibición futbolística, Celli "bebió una cerveza helada y al día siguiente moría víctima de su última travesura infantil" (Borocotó, 1951, p. 160). La disciplina estaba lejos de regular la vida de los futbolistas, y los exámenes de salud no existían. Celli murió por una tuberculosis no diagnosticada, hecho que tomó estado público años después, cuando esa enfermedad ya no era un tabú sociocultural. ${ }^{20}$ En tiempos de Celli, la interiorización del entrenamiento era sensiblemente menor que el capital técnico de los jugadores. Como es visible, los excesos no fueron privativos de los hinchas, tanto las canchas como las tribunas se habían diversificado socialmente.

La falta de rigor y el desborde de apasionamiento abonaron la imagen del jugador nacido y forjado en el potrero. Lejos de la disciplina y el entrenamiento, en la espontaneidad del baldío floreció el talento del futbolista argentino. Antes de la profesionalización, el sacrificio del jugador fue socioeconómico, determinado por la falta de recursos y las condiciones del ama-

${ }^{20}$ Sobre la tuberculosis en Argentina véase Armus (2007). 
teurismo. Entretanto, su cuerpo estaba naturalmente dotado o tonificado por "la voluntad” y "el corazón”. Así, la destreza deportiva permaneció inexplicable y esencializada, resguardada por los esquemas culturales por narraciones mitológicas (Archetti, 2003). Los efectos de esos relatos contribuyeron a la formación de los estereotipos deportivos, y de formas de percepción que devotas de la idea de un "talento sin trabajo" renunciaron a las "fatigas del entrenamiento".

El futbol también fue practicado en la "libertad" de las calles, partidos improvisados comprometieron el tráfico y la urbanidad. La reglamentación que prohibía el acceso a las zonas sembradas de las plazas originó juegos nómadas. ${ }^{21}$ En las imágenes de la prensa de los años veinte, sus jóvenes protagonistas sustituyeron a los niños mendicantes. Pero las autoridades subrayaron la incultura propia de esas prácticas. ${ }^{22}$ El celo del municipio se movía en un terreno inestable. No era bueno que los niños jugaran al futbol en la calle, aunque los partidos eran preferibles al vagabundeo y la mendicidad.

Los jóvenes aficionados experimentaron el deporte desde el cuerpo; inventaron conexiones carnales con la pelota, los adversarios, las reglas y las estrategias. La cultura física, impulsada por el pedagogo del ejercicio Romero Brest en el sentido de una disciplina razonada (Scharagrodsky, 2011) y por el profesor de esgrima Arrospidegaray en el de una obediencia ciega, ${ }^{23}$

${ }^{21}$ Niños y plazas. Guardianes de paseos públicos.

La Capital, 24 de abril de 1929, p. 5.

${ }^{22}$ Football callejero. Plaga que urge reprimir. $\mathrm{La}$ Capital, 5 de octubre de 1927, p. 6.

${ }^{23}$ Sobre las perspectivas de Arrospidegaray y Pignetto véase Roldán (2013, pp. 46-62). finalmente enraizó y floreció entre los sectores populares, pero su eje estuvo en los deportes estandarizados y no en los ejercicios higiénicos o marciales. El juego obtuvo gran influencia popular, su hechizo también se apoderó de agentes con posiciones sociales más aventajadas. Era una práctica cuya circulación social describía un avance transversal. El futbol configuró el triunfo paradojal de la cultura física, capaz de arraigar entre los hábitos de la juventud, aunque bajo formas quizá algo menos rigurosas.

El "mayor peligro" del futbol callejero fue la ausencia de organización. Si el deporte federado solía producir conflictos en los estadios, en los partidos callejeros esas disputas eran frecuentes. Las reglas formaron el componente disciplinario del deporte, un entramado que debía respetarse para alcanzar la victoria legítima. Con la subversión de estos supuestos, los efectos benéficos de la emulación deportiva quedaban anulados. El dispositivo normativo fue torcido por los usos populares del deporte, los agentes disciplinarios creyeron ver allí una ausencia de control y de sistema. Incapaz de producir disposiciones que mejoraran la utilidad social de sus participantes, la práctica paranormativa del deporte se ganó la censura de las autoridades. ${ }^{24}$

Sin embargo, el "apasionamiento descontrolado" no se restringió al futbol callejero, algunos partidos de la LRF también lo actualizaron. ${ }^{25} \mathrm{~A}$ esta presunta "falta de cultura" se imputó la carencia de un "espí-

${ }^{24}$ La Vagancia de los menores. La Capital, 7 de noviembre de 1927 , p. 5; Vagabundaje y analfabetismo. La Capital, 20 de octubre de 1928, p. 5.

${ }^{25} \mathrm{La}$ incultura deportiva. La Capital, 10 de noviembre de 1928 , p. 6. 
ritu deportivo sólido", los espectadores se concentraban en el resultado y no decodificaban adecuadamente la relación entre las reglas y las estrategias. Ese componente "irracional" fue achacado al proceso de difusión social del deporte. Habían aprendido a valorar al futbol en las calles, los potreros, los huecos y baldíos, amaban un futbol con reglas maleables, libre de ataduras, sin estilo colectivo y entregado al triunfo. Ni los futbolistas ni los aficionados asignaron a su práctica dilecta el sentido de la cultura física o las justas caballerescas. Por obra de una mímesis o proyección descontroladas, los estadios también se transformaban en territorios de confrontación más o menos violenta, como lo veremos más adelante.

\section{LOS OTROS}

El centenario difundió la devoción patriótica; esa sensibilidad se ligó tempranamente al futbol. Este fenómeno reconoció una escala latinoamericana (Reyes del Villar, 2004, p. 306). En 1910, Argentina invitó a los combinados uruguayo y chileno a Buenos Aires, el brasileño fue convidado a los festejos del centenario de la declaración de la independencia en 1916. Un año después se instituyó el campeonato sudamericano de selecciones, el equipo argentino triunfó en sus ediciones de 1919,1925 y 1929 , siempre como local. En las olimpiadas de París de 1924, el triunfo de la selección uruguaya capturó la atención de muchos aficionados. El conjunto uruguayo, en los juegos olímpicos de Ámsterdam de 1928, derrotó a Argentina por dos tantos contra uno. Argentina obtuvo el segundo puesto; el arquero del seleccionado nacional fue
Octavio Díaz, que jugaba para el CARC. Esa destacada participación fortaleció el interés local por las competencias internacionales. El golero rosarino manifestó su impresión sobre la coordinación del juego europeo. De manera indirecta sus comentarios elogiaron al estilo rioplatense (criollo).

el juego que tuvo ocasión de presenciar en Europa no es mejor que el que despliegan nuestros cuadros de primera división, y están muy por debajo del juego desplegado por los últimos campeonatos sudamericanos [...] los belgas fueron lo mejor de Europa y nos hicieron frente en un gran partido. Igual que sus demás compañeros, considera que la mala suerte le hizo perder el campeonato que ya habían ganado [...] Los argentinos atacaron constantemente, sin dar tregua a sus adversarios, y han debido ganar por un score abultado. ${ }^{26}$

La copa mundial de 1930 se organizó de espaldas a la cuna británica del deporte y a los juegos olímpicos franceses. El gobierno de Uruguay obtuvo la organización de la copa a través del pago de pasajes y alojamientos gratuitos a todos los equipos participantes y construyó un nuevo estadio con capacidad para 80000 espectadores (Mason, 1995, pp. 31-42). Con ese torneo, que volvió a enfrentar a Uruguay y a Argentina en la final, Sudamérica declaró la autonomía del torneo y mostró el carácter multicéntrico del futbol, un deporte que rápidamente se ramificó en la periferia del globo. Europa tomó revancha organizando los certámenes subsiguientes; uno en la Italia fascista en 1934

${ }^{26}$ Octavio Díaz habla de la gira del seleccionado nacional. La Capital, 17 de junio de 1928, p. 5. 
y otro en Francia en 1938; entre ambos se desarrollaron, bajo los auspicios del nazismo, las olimpiadas de Berlín de 1936. Esos episodios dejaron soldadas, en el plano internacional, las relaciones entre el deporte y la política de masas (Tomlinson y Young, 2006; Vigarello, 1990, pp. 5-10).

La internacionalización impulsó a los aficionados a interrogarse sobre el nivel del futbol local. Para forjar una identidad no existe nada mejor que ponerla en juego. En los últimos años de la década de 1920, los combinados rosarinos enfrentaron a equipos extranjeros de la talla del Barcelona y el Chelsea. En ambos partidos, Octavio Díaz fue suplantado en la valla por un joven del Club Atlético Belgrano, Carlos Guida. El equipo no fomentaba pronósticos optimistas. Uno de sus mejores hombres estaba fuera de la cancha y el Barcelona había derrotado al poderoso equipo de Boca en Buenos Aires. Todo indicaba que los rosarinos perderían, pero contra las predicciones ganaron por cuatro a cero.

El arquero del Barcelona declaró: "no hay disparidad entre el juego que se practica aquí con el de Buenos Aires. A mi juicio la misma técnica, la misma modalidad e igualdad de decisión." 27 Aseguró que el desempeño y la regularidad de juego lo sorprendieron, destacó especialmente la concentración de los defensores y el arquero. Por la noche hubo una cena de camaradería, un jugador catalán preguntó a Indaco, el goleador del CARC, sobre la cabriola con patada llamada chilena. Forjado en los campeonatos sudamericanos, el estilo rioplatense intrigaba

\footnotetext{
${ }^{27}$ El seleccionado rosarino. La Capital, 18 de agosto de 1928, p. 6.
}

a los europeos, y en ese trayecto el futbol rosarino se integraba al mítico estilo criollo. La competencia, las identidades y los rivales internacionales lo ubicaron en paridad con el futbol rioplatense. El juego local se emparentó con el bonaerense y fue reconocido como parte del futbol argentino. En 1925, Julio Libonatti, del CANOB, fue transferido al CA Milan. Octavio Díaz, pocos años después, en 1927, alcanzó la titularidad en el arco de la selección, y Gabino Sosa encarnó el estilo criollo en la ciudad. A partir de esta cadena de acontecimientos lo local y lo nacional se interconectaron.

El combinado rosarino se midió con el Chelsea Football Club en 1929. En los días previos se ponderó el estilo autóctono a través de interpretaciones que enfatizaron la estandarización británica. La efectividad, velocidad y serenidad anglosajonas contrastaron con el virtuosismo y apasionamiento argentinos. ${ }^{28}$ Posteriormente, la crónica adjudicó la victoria del equipo local al "amor propio", el "orgullo" y el "tesón”. Todas formas de la "vergüenza deportiva”.

La valoración del juego del combinado rosarino ante el Barcelona y el Chelsea hizo gala de algunos estereotipos sobre el estilo criollo. Pero, como lo insinúa Julio Frydenberg (2011), esos valores no eran puros. Las descripciones que tematizan el estilo de juego en dos partidos disputados casi por el mismo equipo, con menos de un año de diferencia, uno frente a los catalanes y otro ante los ingleses, poseen un carácter híbrido. En la primera se insiste en la idea de talento, refinamiento y estética del juego local que arrancó a un

\footnotetext{
${ }^{28}$ Chelsea vs. el combinado rosarino. La Capital, 17 de junio de 1929 , p. 5.
} 
equipo difícil un resultado extraordinario e inesperado. Las maneras del futbol rosarino privilegiarían el despliegue vistoso y audaz, por encima de la coordinación y la cautela. Por el contrario, en la segunda crónica se invocaba el empeño, la pertinacia y la obstinación de los jugadores rosarinos, un tesón que nunca se dejó doblegar y que resultó en una forma de juego poco lucida pero eficaz. Como lo exponen estas recapitulaciones, el futbol rosarino, pero quizá también el porteño y por transitividad el argentino, recorrían un terreno incierto a la hora de fraguar su propia identidad, los valores con los que se identificaron fueron tan cambiantes y flexibles como las condiciones de cada partido.

\section{POSICIONES FRENTE A LA PROFESIONALIZACIÓN}

El tránsito del amateurismo al profesionalismo generó discusiones que permiten analizar las relaciones entre el deporte y la moral; entre grupo social y mercado. Constituyen una oportunidad para comprender el vínculo entre las posiciones sociales y los esquemas culturales.

La Liga Argentina de Football (en adelante LAF) se formó en 1931. Luego de una huelga de jugadores, convocó a profesionalizar los equipos de los principales clubes porteños (Frydenberg, 2005, pp. 73-94). Poco después y con propósito idéntico, se fundó la Asociación Rosarina de Football (en adelante ARF), que sustituyó a la antigua LRF. Esa simultaneidad obedeció a conflictos análogos registrados entre clubes y equipos, la ARF intuyó la necesidad de profesionalizar el futbol para evitar la migración masiva de jugadores a Buenos Aires. El juego profesional era una oportunidad seductora para los futbolistas, pero el dinero tan sólo era una parte del convite, el prestigio de los equipos porteños quizá resultara más atractivo.

Para frenar el impulso de la profesionalización se creó la Asociación de Football Amateur de Rosario (AFAR). Desde 1929, en diez canchas del barrio Moderno se jugó un torneo de clubes independientes. Según su impulsor, la iniciativa "tiende exclusivamente a fomentar el cultivo viril del deporte [...] existe el firme propósito de excluir de tales reuniones toda idea y espíritu de profesionalismo". ${ }^{29}$ Ese torneo enfrentó a 50 clubes carentes de campo y afiliación a otras ligas. Deliot, el urbanizador del barrio, cedió los terrenos "a los aficionados del deporte, siempre que lo practiquen con cultura y desinterés". 30 Del encuentro de estos clubes con los excluidos de la LRF surgió la AFAR, pero si el torneo no sirvió para cotizar jugadores, valorizó, en cambio, los terrenos aledaños a las canchas. Los mismos que Deliot vendía por mensualidades. El empresario había solicitado personalmente la extensión de transportes para el público y los jugadores, pero que también colocaban en una posición ventajosa sus propiedades en el mercado de tierras. La estrategia económica de Deliot mostró cómo el "desinterés deportivo" camuflaba un "interés inmobiliario”.

Mientras el amateurismo exhibía endebles convicciones, los adversarios de la pro-

${ }^{29}$ Campeonato de clubes independientes. $\mathrm{La}$ Capital, 15 de junio de 1929, p. 5.

${ }^{30}$ Carlos Deliot ofreciendo gratuitamente a la comuna un terreno. 31 de abril de 1932. Expedientes Terminados del Honorable Concejo Deliberante. Noviembre 1934, t. 1, f. 3702. ACMR, Argentina. Énfasis añadido. 
fesionalización empleaban otros argumentos. Ellos indicaron que la monetización del deporte lo envilecería, los clubes se convertirían en los amos de los jugadores que formarían legiones de esclavos. El deporte sería deshumanizado por el mercado y la competencia. Los defensores de estas posturas clamaron por un retorno "al deporte por el deporte mismo. Su industrialización e internacionalización ha determinado prejuicios físicos, morales y espirituales." 31

Con matices, esas ideas fueron impulsadas por las elites, algunos segmentos que ascendían en el espacio social, los partidarios de la fisiología del ejercicio y la izquierda. Para ellos, la profesionalización constituía un hecho aberrante. Por una posición conquistada, el afán de obtenerla o la aversión al mercado, estos grupos repudiaron el salario deportivo. Los de posición asegurada valoraron al deporte como signo de distinción: pocos debían consagrarse al sport en tanto lucha caballeresca y honorable. El resultado de la competencia no acaparaba todo el sentido. Para los miembros de los clubes de origen inglés el deporte era un juego de honor, masculinidad, refinamiento y sofisticación, regido por el fair play y del que convenía excluir a las "multitudes intemperantes”. Los menos encumbrados destacaron el esfuerzo deportivo y sus implicancias físicas y morales. A sus ojos, las prácticas corporales acéticas y sistemáticas compartían elementos sacrificiales con las virtudes laborales que conducían al ascenso social. Asimismo, la "futbolización" de la cultura física, reforzada por la profesionalización, fue criticada por los

${ }^{31}$ El deporte y su irracional utilización. La Capital, 21 de octubre de 1933, p. 6. higienistas y los profesores de educación física, que observaron con preocupación su introducción en las escuelas como el relevo monodeportivo de la gimnasia racional.

La izquierda percibió en la profesionalización del futbol un síntoma de la expansión del capitalismo. Simultáneamente, los espectáculos masivos se revelaron capaces de perpetuar el orden y, en esta interpretación, el futbol resultó un dispositivo alienante. La devoción por las Iglesias fue reemplazada por las atracciones del estadio y los partidos se ubicaron bajo las brumas del antiguo "opio de los pueblos”. No en vano, intuían los comunistas, los directores del ferrocarril utilizaron el futbol para armonizar las relaciones laborales.

Desde su banca de concejal, Muñoz Diez atacó el proceso de mercantilización del deporte y subrayó la complicidad del Estado capitalista a la hora de prestarle auspicios. Sin embargo, el concejal comunista no repudió la práctica en sí misma. En su concepto, el deporte era una herramienta de concientización y politización, pero también un cascarón vacío capaz de captar los atributos de quienes lo organizaran. El futbol no era una relación social sino un instrumento; al igual que al Estado, podía utilizárselo como garantía de la perpetuación del capitalismo y herramienta represiva, o como la llave de una revolución proletaria.

nos oponemos a que se privilegie al deporte capitalista, al deporte que, con el pretexto de un ejercicio popular, aparentemente neutral, fomenta los prejuicios burgueses y hace deliberadamente la propaganda ideológica a favor de la explotación existente. Todos los cuerpos colegiados y las diversas ramas 
administrativas del Estado, se preocupan por fomentarlo. Es natural esto se hace porque conviene a los intereses políticos de las clases dominantes. Sin duda alguna no se trata de elevar la cultura física de masas. Hoy los principales jugadores de los clubs de foot-ball perciben sueldos [nótese que el profesionalismo aún no se hallaba formalizado], obtienen favores que hacen de ellos profesionales del deporte. Mal se puede elevar en esa forma la cultura física [...] se busca especular políticamente tratando de hacer ver que se ocupan de su salud física. Pero esta farsa se pone al descubierto ante la actitud de los señores concejales [...] al oponerse a sanciones inmediatas de mejoras para las masas [...] Además, los que hablan de cultura física y pregonan la salud del pueblo, solamente; con un régimen de salarios de hambre, con viviendas antihigiénicas, falta de luz y de aire y de elementales comodidades, debiendo habitar en piezas de cuatro por cuatro ocho, nueve y más personas iy después se llenan la boca hablando de cultura física y salud del pueblo! Se trata de beneficiar y sostener el deporte burgués, el deporte mercantilista. ${ }^{32}$

A ojos de Muñoz, las justas por el honor elitista, el sacrificio burgués o la cultura física nacionalista-higienista eran por completo irrelevantes. El deporte debía ser ante todo un apresto para la lucha de clases. Los nacionalistas, como Juan Bautista Arrospidegaray y Manuel Pignetto, creyeron que el deporte era una preparación para la guerra de trincheras, el trabajo fabril y el mejoramiento racial y moral. En cambio, los comunistas, como

${ }^{32}$ Campeonato de futbol. Felicitación y medalla de oro. Diario de Sesiones del Honorable Concejo Deliberantes. 15 de octubre de 1929. ACMr, Argentina.
Muñoz Diez, consideraban que produciría militantes sanos, fuertes y convencidos para combatir por la revolución y trabajar en la construcción del socialismo. El mejoramiento racial y el hombre nuevo surgirían de la cultura física higienista o del deporte socialista. En ambos casos estaba en juego una preparación para la guerra y el trabajo, la divergencia radicaba en si estos procesos se llevarían a cabo en el campo nacional o en el socialista.

Una fracción significativa de los sectores populares era ajena a las apreciaciones del ethos sacrificial, caballeresco o contestatario del deporte. Ellos se dejaron tentar por la profesionalización. La existencia de deportistas talentosos fue su condición necesaria, la dedicación exclusiva al deporte apuntaba a preservar a esos virtuosos de otras labores. El horizonte de trabajo de muchos jóvenes fue plegado por la crisis económica de 1929. Aunque posiblemente las compensaciones económicas no fueran demasiado abultadas, el futbol profesional forjó la esperanza de un puesto de trabajo socialmente reconocido y agradable. La vinculación del futbol con el mercado promovió analogías entre el club y la empresa, entre los jugadores y los asalariados. Esa compensación económica organizó los intereses de los dirigentes, los jugadores y los entrenadores alrededor de la victoria. La profesionalización formó las condiciones de absorción del juego en el trabajo. Un contrapunto entre fuerza y habilidad informó los debates alrededor del futbol. Los juegos de honor fueron subalternizados, exigiéndose el cultivo de nuevas aptitudes y la moderación de otras. La emotividad desordenada fue tendencialmente reprimida y la illusio del juego fue encausada hacia el resultado. El jugador se transformó en un empleado del club, 
no jugaría por placer, antes estaba obligado a conquistar más puntos y prestigio.

$\mathrm{El}$ adiestramiento supuso un ajuste en la coordinación, una idea que fue bastante resistida inicialmente por los jugadores, quienes preferían inspirarse en el toque, la gambeta y la improvisación. Muy lentamente y con dificultades, los entrenamientos se introdujeron en el futbol. La profesionalización impulsó ensayos para el acople de formaciones variables, procuradas por el mercado de pases. Esos simulacros permitieron a los jugadores ejecutar velozmente movimientos preparados. Los entrenamientos supusieron un atajo para la maduración y la eficacia del juego colectivo. Aquí existe un tema que permitiría observar desde un punto de vista acaso inverso los temores que los higienistas proyectaban en la futbolización de la cultura física. El entrenamiento constituye una fisura de la cultura futbolística, el intersticio por el que la cultura física, lentamente, se infiltró hasta inocularse en el futbol profesionalizado. El entrenamiento significó una subordinación del juego a sus aprestos, del estilo al sistema o a cierta condición física. Pero imponerlo como práctica regular no fue sencillo, hubo resistencias interpuestas por los jugadores al régimen alimentario y la ejercitación periódica.

En los años treinta, el futbolista fue (re)conocido como el dominador de un arte, de una técnica que podía ser ingénita, casi natural, o conquistada con el esfuerzo del entrenamiento.

\section{LA CONFIGURACIÓN DEL ESPECTÁCULO DEPORTIVO}

La legalización del pago a jugadores y la mercantilización del futbol potenciaron la expectativa social, las tribunas se poblaron de espectadores. En la década de 1920, un conglomerado de agencias había construido trabajosamente, pero no necesariamente de modo consciente y/o cooperativo, las condiciones de posibilidad de lo que una década después se consagró como un espectáculo masivo. El transporte suele ser un buen indicador de las derivas generadas por los nuevos rituales populares. Prestado desde 1928 por Farot y Baboni, el servicio de "Ómnibus de Excursión" contaba con los atractivos de algunos rincones pintorescos de Rosario: Saladillo, Fisherton, Alberdi, y el Parque de la Independencia. Dos años después, los recorridos de esos coches mostraban otros centros de interés. ${ }^{33}$ Las denominaciones de esos itinerarios eran "a Cancha de Rosario Central", "a Cancha de Newell's Old Boys”, "a Cancha de Central Córdoba” y "a Cancha de Tiro Federal”, cuatro clubes que, en 1931, formaron parte de la ARF, la asociación que impulsó la profesionalización del futbol. Cuando el capitalismo avanza hacia el consumo masivo, la red de transportes urbanos comienza a reconfigurarse siguiendo las localizaciones de las nuevas atracciones capaces de movilizar a multitudes e incrementar el corte de boletos y satisfacer las demandas de los usuarios. A partir de los años treinta, las excursiones dominicales no se dirigieron, como lo habían hecho pocos años atrás, hacia los barrios pintorescos, sino que se encaminaron a los campos de futbol de Rosario. ${ }^{34}$

33 Ómnibus de Excursión. Diario de Sesiones Honorable Concejo Deliberante. 14 de septiembre de 1928, pp. 596-598. ACMr, Argentina.

${ }^{34}$ Circulación de ómnibus de excursión. Diario de Sesiones Honorable Concejo Deliberante. 21 de mayo de 1930, pp. 204-205. ACMR, Argentina. 
A los concejales Hernández y Dall'Orso la dotación de ómnibus destinados a servir las canchas de los clubes más importantes les pareció una medida adecuada y urgente. Ambos comprendían que el flujo de espectadores no podía ser encauzado por los transportes regulares, era necesario disponer de un servicio excepcional y de refuerzo. Cuando finalizaban los partidos, en las calles adyacentes a los estadios se daba cita una asombrosa concentración de peatones, todos se agitaban nerviosos en pos de transporte. Después de las decepciones de rigor, establecidas por tranvías y ómnibus completos que esquivaban las paradas, los peatones se resignaban a emprender una larga marcha. Había que acondicionar el transporte y subordinarlo a las exigencias de los nuevos espectáculos dominicales. Estadísticamente los partidos de futbol se coronaban como una de las atracciones más favorecidas por los rosarinos, las otras eran el cinematógrafo y las carreras de caballos (Anuario, 1936, p. 81).

Distintas evidencias concurren a demostrar las características masivas que entornaron al espectáculo futbolístico en los años treinta. La edilicia de los estadios fue modificada, las tribunas tradicionalmente de madera pasaron a ser construidas a base de cemento para asegurar a los numerosos concurrentes. En 1932 se obligó a los clubes a levantar en sus estadios, especialmente en el área de las tribunas populares, numerosos baños. ${ }^{35}$ Asimismo se impulsó la colocación de sistemas lumínicos de relativa potencia para los encuentros nocturnos de verano. Estas

${ }^{35}$ Proyecto del concejal De Sanctis, mingitorios en espectáculos al aire libre. 7 de abril de 1932. Expedientes Terminados del Honorable Concejo Deliberante. Mayo 1932, t. II, f. 2897. ACMr, Argentina. innovaciones respondieron a la interdicción, instaurada en 1926, respecto a los partidos de futbol durante los meses estivales. ${ }^{36} \mathrm{La}$ iluminación artificial cumplió una función parcial, la mayor parte de los clubes era incapaz de asumir los costos de estas innovaciones.

No pasó inadvertida la masividad del futbol para el municipio, que propuso nuevos gravámenes, legitimados por la oficialización del profesionalismo. ${ }^{37} \mathrm{El}$ gobierno local intentó regular la edilicia de los estadios, sobre todo en lo concerniente a su desalojo. Así, reglamentó un incremento en el ancho y la cantidad de puertas de ingreso y egreso a los estadios. Esta normativa obedecía a la manifestación intempestiva y a veces también violenta de las pasiones vinculadas al futbol. Las precarias condiciones arquitectónicas que imperaban en los estadios impedían desalojar rápidamente las canchas en caso de que ocurrieran incidentes. Para evitar posteriores trastornos, que complicasen la situación de los espectadores y su relación con la policía, se procurarían grandes puertas a modo de salidas de emergencia. La ampliación de las entradas y salidas no fue establecida por posibles catástrofes, como los incendios o los derrumbes frecuente-

${ }^{36}$ La prohibición se había ampliado en 1933; en la nueva ordenanza no se autorizaban partidos en el municipio entre las 8 y las 20 horas. De no ser que se contara con un sistema de iluminación artificial, quedaban pocas para continuar con el desarrollo del futbol en verano. Diario de Sesiones Honorable Concejo Deliberante. 30 de noviembre de 1934, t. 2, p. 1895. ACMR, Argentina.

37 Proyecto de varios señores concejales sobre impuestos a espectáculos de futbol. 29 de marzo de 1932. Expedientes Terminados del Honorable Concejo Deliberante. Octubre 1932, ff. 6566-6568. ACMR, Argentina. 
mente invocados en las reglamentaciones de salas teatrales y cinematógrafos, en cambio, su construcción obedeció a la irrupción de la violencia y la represión en las tribunas. $^{38}$

La obsesión por el futbol creció junto con la disponibilidad de nuevos medios de comunicación consagrados a cubrir sus alternativas. Por una parte, la prensa gráfica, los diarios Reflejos y la sección deportiva de Tribuna destinaron una fracción muy importante de sus ediciones de los lunes a reseñar las alternativas del campeonato local y porteño. Incluso existían pequeñas columnas que recogían las opiniones de los aficionados, en las que aparecían "simpáticas e ingeniosas" referencias y semblanzas de las figuras más destacadas de los diversos equipos. Periódicos menos populares como La Capital prestaron gran atención a los cotejos, reservándoles de dos a tres páginas en su edición de los lunes varias fotografías, aunque para narrar el deporte emplearon un lenguaje que integraba subordinadamente los apasionamientos populares. El trabajo radiofónico, concentrado por La Voz del Deporte, programa trasmitido por LT3 y conducido por Cipriano Roldán, estimulaba el interés de la afición por los partidos y contribuía a crear gran expectativa en torno a los encuentros internacionales y los clásicos locales.

Las tribunas disputaron el protagonismo con el campo de juego, el compor-

38 Proyecto de los concejales Imbert y Perfumo sobre la construcción de puertas anchas en las canchas de futbol. 21 julio 1934. Expedientes Terminados del Honorable Concejo Deliberante. Junio 1934, f. 1904; Diario de Sesiones Honorable Concejo Deliberante. 17 de julio de 1934, p. 779. ACMr, Argentina. tamiento de los aficionados fue observado por periodistas e intelectuales como un hecho "irracional”. Quienes desconocían los atractivos del juego creyeron que el futbol apenas disimulaba un "combate corporal bárbaro”. Las explosiones de violencia dentro y fuera del terreno fueron adjudicadas a la incultura y a la excesiva atención que espectadores y jugadores tributaron al resultado. Ambas inclinaciones fueron entendidas como parte de las consecuencias de la popularización del deporte.

Como se ha visto, fueron los árbitros el temprano y privilegiado blanco de innumerables agresiones. ${ }^{39} \mathrm{~A}$ menudo, los exabruptos y algunos episodios violentos producidos dentro y fuera del campo precipitaron la represión policial. Para la prensa tradicional, la masividad y la popularización del futbol resultaron inquietantes, se les achacó la "degeneración del deporte”. La cultura popular habría trasladado a los estadios su "esencial intemperancia", la estigmatización periodística instó a ese tipo de público a una pasividad y una tranquilidad férreamente vigiladas por la policía. Sin embargo, tanto las regulaciones deportivas como las extradeportivas fueron insuficientes cuando se trató de encauzar esos hábitos.

Pero la sensibilidad de los hinchas no sólo tendió a la violencia y la agresividad, acaso las crónicas hayan exagerado esa faceta. La mayor parte del tiempo los aficionados experimentaron una confrater-

${ }^{39}$ Esto también es una realidad que afecta al futbol cordobés. Según Franco Reyna muchos de los árbitros eran ex jugadores o tenían algún vínculo con alguno de los clubes a los que arbitraban. De forma que su imparcialidad quedaba bajo sospecha (Reyna, 2011, p. 101). 
nidad simbólica. Los simpatizantes espacio-temporalmente compartieron algo intangible, aunque acotado, eran los miembros de una comunidad imaginada sostenida por el club de futbol.

Esa "comunidad de la hinchada" se formó en un sinfín de intercambios y encuentros replicados en el tiempo por los campeonatos y los partidos, y en el espacio por la infraestructura del club, por los sitios de reunión y la comunidad barrial. La afición construyó una historia mitológica, incierta y discutible, pero trasmisible y operativa. Esas narrativas fecundaron una identidad cerrada y purificada, destinada a una glorificación tan amplia como improbable. En esos relatos, las mitologías nacionales y futbolísticas no sólo se intersecan, sino que responden a una analogía estructural. Esa comparación propone simetrías capaces de explicar parcialmente las proximidades prácticas entre los significantes futbol y nación (Alabarces, 2002).

Los hinchas no sólo construyeron mitos y confraternizaciones, las comunidades siempre fueron y son imaginadas, incluso las futbolísticas. En el aglutinante del ritual, se diluyeron las diferencias, aunque algunos de sus fragmentos pervivieron: "las tribunas oficial [de socios] y popular [de aficionados no socios] están separadas por alambres y tabiques que impiden su comunicación, evitando así que los de una categoría pasen a otra". ${ }^{40}$ Es posible formar parte de una comunidad, pero los capitales amasados en otros campos rigen la distribución espacial de los agentes aun dentro de ella. El alambrado de la tribuna

${ }^{40}$ Proyecto del Concejal De Sanctis, mingitorios en espectáculos al aire libre. 7 de abril de 1932. Expedientes Terminados del Honorable Concejo Deliberante. Mayo 1932, t. II, f. 2897. ACMr, Argentina. fractura, clasifica, reordena, lo masivo también reconoce diferenciaciones internas, las mismas con las que los aficionados deben reencontrarse al salir de la cancha.

\section{CONCLUSIONES}

Este artículo se propuso reconstruir el proceso de difusión del futbol en Rosario a partir de cinco entradas. La primera se ocupa de estudiar la introducción del futbol por parte del Club Atlético Rosario, la posterior formación de clubes de orígenes diversos (empresas, colegios, barrios, etc.), el lanzamiento de una Liga Rosarina de Futbol, la organización de las primeras competencias locales, la aparición de los conflictos, frecuentemente insalvables, entre los ideales del fair play y un juego y una atención tendencialmente focalizados sobre el resultado. El segundo apartado se propone mostrar los primeros pasos de la difusión social del deporte a través de dos acontecimientos: un partido amistoso con Boca Juniors tras la exitosa gira europea del equipo porteño y la muerte y sepelio de uno de los emblemas del futbol local: Ernesto Celli, quien falleció luego de un amistoso entre Newell's Old Boys y Nacional de Montevideo (Uruguay). En esas páginas se exploran las modalidades que adoptaron en una escala local la forja del estilo criollo, el nuevo arraigo de las figuras deportivas y la paulatina popularización del futbol como práctica corporal, tanto en los estadios como en espacios públicos y calles de la ciudad. Posteriormente, se propone enlazar futbol e identidad a través de problemas vinculados a la nación y el estilo deportivo. En el plano nacional, esa producción de identidades se exhibe primariamente ligada a los par- 
tidos celebrados con motivos de los dos centenarios argentinos (1910-1916) y a las destacadas campañas de la selección argentina en las olimpiadas de Ámsterdam 1928, el campeonato sudamericano de 1927 y la copa del mundo de Uruguay 1930. En Rosario, aparece con mucha presencia en una relación de contigüidad con dos partidos amistosos internacionales disputados por el combinado rosarino de futbol con el equipo catalán de Barcelona (1928) y el británico Chelsea (1929). Estos eventos junto a sus comentarios, produjeron sentido acerca del entroncamiento rioplatense del estilo futbolístico practicado en Rosario y la sintonía del futbol local con el nacional. El cuarto apartado se ocupa de reconstruir las posiciones y conflictos alrededor de la profesionalización del futbol, acaecida a comienzos de la década de 1930. Clivajes sociales, políticos y culturales configuran las valoraciones positivas o negativas de los agentes sociales y grupos políticos respecto al futbol como práctica vinculada al mercado y la explotación económica. Allí desempeñaron un papel relevante la posición ocupada dentro del espacio social, las políticas e ideologías de izquierdas y la adscripción al ideario y las prácticas de la cultura física. Finalmente, se explora el proceso de masificación del deporte a través de la reconstrucción de la red de transporte público urbano, los flujos humanos que llegaban hasta y salían desde las canchas, la edilicia de los estadios, la atención prestada primero por los diarios y luego por la radio a las prácticas futbolísticas y la estabilización de la figura del hincha.

La incorporación del CARC y del CANOB al campeonato nacional de futbol, en 1939, exacerbó el fanatismo y sumó nuevos seguidores. Finalmente, el futbol rosa- rino obtuvo la ansiada carta de ciudadanía en el nivel nacional. A partir de entonces, la práctica se argentinizó ostensiblemente. La Asociación del Futbol Argentino (AFA), fundada en 1934, eliminó la designación anglosajona del deporte. La popularización y la nacionalización del futbol fueron un hecho para 1940. Los sectores populares se apropiaron del deporte, cargándolo con sus códigos de masculinidad y dignidad. El resultado del proceso de difusión social fue un efecto no deseado para los amantes del sport pour le sport y de la cultura física. Los intercambios entre las tribunas construyeron multitudes, donde las identidades sociales fueron debilitadas y circunstancialmente sustituidas por las deportivas. Los defensores de la cultura física, críticos de la profesionalización y de la popularización del futbol, debieron afrontar la irrevocabilidad de ese proceso. Sus valores fueron conmovidos por la maquinaria del mercado que organizó el deporte. En noviembre de 1938, Ricardo Martínez Carbonell (1938) escribía en la revista socialista Cultura Sexual y Física:

La palabra deporte parece que siempre lleva algo de competencia [...] es un inconveniente para que los adopte como mediada de educación física, cuyo único objeto es el desarrollo armónico del cuerpo (p. 198).

Quince años después, Martínez Carbonell asumía la dirección técnica del CANOB. La cultura física había perdido la pulseada, el mercado, las masas y el deporte profesional la acorralaron hasta absorberla en el backstage del espectáculo futbolístico. 


\section{LISTA DE REFERENCIAS}

-Alabarces, P. (2000). Introducción. Los estudios sobre deporte y sociedad: objetos, miradas, agendas. En Peligro de gol. Estudios sobre deporte y sociedad en América (pp. 11-25). Buenos Aires: Clacso.

-Alabarces, P. (2002). Futbol y Patria. El futbol y las narrativas de la nación en la Argentina. Buenos Aires: Prometeo.

-Anuario Estadístico 1935 (1936). Rosario: Talleres Gráficos Emilio Fenner.

-Anuario Estadístico 1940 (1941). Rosario:

Talleres Gráficos Emilio Fenner.

-Appadurai, A. (1991). La vida social de las cosas. Perspectiva de las mercancias. México: Grijalbo.

-Archetti, E. (1995). Estilo y virtudes masculinas en $E l$ Gráfico: la creación del imaginario del futbol argentino. Desarrollo Económico, 35(139), octubre-diciembre, 419-442, Buenos Aires.

-Armus, D. (2007). La ciudad impura. Salud, tuberculosis y cultura en Buenos Aires 1870-1950. Buenos Aires: EDHASA.

-Bailey, T. (1979). A History of Cricket. Winchester: Allen \& Unwin.

-Borocotó, R. (1951). Lorenzo 30 años con el deporte. Buenos Aires: Editorial Atlántida.

-Bossio, A. (1990). Los orígenes del futbol en Rosario. Rosario: Ediciones de Aquí a la Vuelta. -Centenario del Club Atlético del Rosario-Plaza Jewell (1967). Historia de 100 años de deporte amateur 1867-1967. Rosario: Amalevi.

-Curry, G. (2001). Football: Study in diffusion (Tesis doctoral). University of Leicester.

-Dellacasa, J. (1939). Puntapié penal, s. e.

-Dyck, N. y Archetti, E. (eds.) (2003). Sport, dance and embodied identities. Nueva York: Berg.

-Elias, N. y Dunning, E. (1992). El futbol en Gran Bretaña durante la Edad Media y comienzos de la Edad Moderna. En El deporte y el ocio en el proceso de civilización (pp. 231-246). México: FCE.
-Farias, D. y Gauna, J. (1994). Masas y elites: en los orígenes del futbol rosarino (1870-1943). (Tesis de licenciatura), Universidad Nacional de Rosario, Argentina.

-Fishwick, N. (1989). English football and society 1910-1950. Manchester: Manchester University Press.

-Frydenberg, J. (2005). La profesionalización del futbol argentino: entre la huelga de jugadores y la reestructuración del espectáculo. Entrepasados, 27, 73-94.

-Frydenberg, J. (2011). Historia social del futbol: del amateurismo a la profesionalización. Buenos Aires: Siglo XXI Editores,

-Gayol, S. (2000). Sociabilidad en Buenos Aires. Hombres, honor y cafés 1862-1910. Buenos Aires: Ediciones del Signo.

-Holt, R. (1992). Sport and the British. Oxford: Oxford University Press.

-Martínez Carbonel (noviembre, 1938). Cultura física y deporte. Cultura Sexual y Física, año 2, II, 198, Buenos Aires: Claridad.

-Mason, T. (1980). Association Football and English Society 1863-1915. Brighton: Harvester Press.

-Mason, T. (1995). Passion of the people? Football in South America. Londres: Verso.

-Nauright, J. y Chandler, T. (eds.) (1996). Making men. Rugby and masculine identity. Londres: Frank Cass.

-Olivera, E. A. (1932). Los orígenes de los deportes británicos en el Río de La Plata. Buenos Aires: Talleres Gráficos JL Rosso.

-Reyes del Villar, S. (2004). Chile en 1910: Una mirada cultural en su centenario. Santiago de Chile: Sudamericana.

-Reyna, F. D. (2011). Cuando éramos footballers. Una bistoria sociocultural del surgimiento y la difusión del futbol en Córdoba (1900-1920). Córdoba: Centro de Estudios Históricos "Prof. Carlos S. A. Segreti”.

-Rinke, S. (2007). ¿La última pasión verdadera? Historia del futbol en América Latina 
en el contexto global. Iberoamericana, VII(27), 58-100.

-Roldán, C. (1959). Anales del futbol rosarino. Rosario: Talleres San José.

-Roldán, D. P. (2013). Espacios urbanos, disciplinas y nación. Polígonos de tiro, colonias de vacaciones y estadios públicos. Rosario 1900-1940. Revista Estudios del ISHiR, año 3 (5), 46-62.

-Scharagrodsky, P. (2011). La constitución de la educación física escolar en la argentina Tensiones, conflictos y disputas con la matriz militar en las primeras décadas del siglo Xx. En P. Scharagrodsky (ed.), La invención del homo gymnasticus. Fragmentos históricos sobre la educación de los cuerpos en movimiento en Occidente. Buenos aires: Prometeo.

-Tomlinson, A. y Young, Ch. (eds.) (2006). National identity and global sport events. Culture, politics, and spectacle in the Olympics and the football world cup. Nueva York: State University of New York Press.

-Vigarello, G. (1990). Les premières coupes du monde, ou l'instalation du sport moderne. Vingtième Siècle. Revue d'bistoire, 26(1), 5-10.

\section{OTRAS FUENTES}

\section{Archivo}

ACMR Archivo del Concejo Municipal de Rosario, Argentina.

\section{Hemerografía}

Monos y Monadas, 1910-1911.

La Capital, 1925; 1927; 1928; 1929; 1933 у

1934.

\section{Bibliografía}

-Alabarces, P. (org.) (2005). Hinchadas. Buenos Aires: Prometeo.

-Arbena, J. (1988). Sport and Society in Latin America. Diffusion, dependency and the rise of mass culture. Nueva York: Greenwood.

-Archetti, E. (2001). El portero, la pista y el ring. Las patrias del deporte argentino. Buenos Aires: FCE.

-Archetti, E. (2003). Masculinidades. Futbol, tango y polo en la Argentina. Buenos Aires: Antropofagia.

-Bourdieu, P. (1997). La ilusión biográfica. En Razones prácticas sobre la teoría de la acción (pp. 74-83). Barcelona: Anagrama.

-Bromberger, Ch. (1995). Le match de football. Ethnologie d'une passion partisane à Marseille, Naples et Turin. París: Maison des sciences de l'homme.

-Lowenthal, L. (1984). Literature and Mass Culture. Nueva Brunswick-Londres: Transaction Books.

-Holt, R. (1981). Anglaterre: le 'foot', l'ouvrier et le bourgeois. L'Histoire, 38, octubre, París.

-Ongay, O. (1991). Rosario, futbol y recuerdos. Rosario: Editorial Amalevi.

-Viale, C. (1922). El atleta. En Deporte argentino (contribución a su desarrollo y prosperidad). Buenos Aires: Librería de García Santos 